\title{
Assessing Regional Scale Water Balances through Remote Sensing Techniques: A Case Study of Boufakrane River Watershed, Meknes Region, Morocco
}

\author{
Mohammed El Hafyani ${ }^{1, *}$, Ali Essahlaoui ${ }^{1}$, Anton Van Rompaey ${ }^{2}\left(\mathbb{D}\right.$, Meriame Mohajane $^{1,3}$ AD, $^{\text {, }}$ \\ Abdellah El Hmaidi ${ }^{1}$, Abdelhadi El Ouali ${ }^{1}$, Fouad Moudden ${ }^{1}$ and Nour-Eddine Serrhini ${ }^{4}$ \\ 1 Department of Geology, Laboratory of Geoengineering and Environment, \\ Research Group “Water Sciences and Environment Engineering”, Faculty of Sciences, \\ Moulay Ismail University, Zitoune, Meknès BP 11201, Morocco; a.essahlaoui@fs-umi.ac.ma (A.E.); \\ mohajane.meriame13@gmail.com (M.M.); a.elhmaidi@fs-umi.ac.ma (A.E.H.); \\ a.elouali@fs-umi.ac.ma (A.E.O.); moudden2000@yahoo.fr (F.M.) \\ 2 Department Earth and Environmental Science, Geography and Tourism Research Group, KU Leuven, \\ Celestijnenlaan 200E, 3001 Heverlee, Belgium; anton.vanrompaey@kuleuven.be \\ 3 Department of Biology, Research Group "Soil and Environment Microbiology Unit", Faculty of Sciences, \\ Moulay Ismail University, Zitoune, Meknès BP 11201, Morocco \\ 4 Sebou Hydraulic Basin Agency, Fès BP 2101, Morocco; serininour@yahoo.fr \\ * Correspondence: m.elhafyani@edu.umi.ac.ma; Tel.: +212-7063-5119
}

Received: 15 December 2019; Accepted: 16 January 2020; Published: 21 January 2020

check for updates

\begin{abstract}
This paper aims to develop a method to assess regional water balances using remote sensing techniques. The Boufakrane river watershed in Meknes Region (Morocco), which is characterized by both a strong urbanization and a rural land use change, is taken as a study case. Firstly, changes in land cover were mapped by classifying remote sensing images (Thematic Mapper, Enhanced Thematic Mapper Plus and Operational Land Imager) at a medium scale resolution for the years 1990, 2003 and 2018. By means of supervised classification procedures the following land cover categories could be mapped: forests, bare soil, arboriculture, arable land and urban area. For each of these categories a water balance was developed for the different time periods, taking into account changing management and consumption patterns. Finally, the land cover maps were combined with the land cover specific water balances resulting in a total water balance for the selected catchment. The procedure was validated by comparing the assessments with data from water supply stations and the number of licensed ground water extraction pumps. In terms of land use/land cover changes (LULCC), the results showed that urban areas, natural vegetation, arboriculture and cereals increased by $183.74 \%, 12.55 \%, 34.99$ and $48.77 \%$ respectively while forests and bare soils decreased by $78.65 \%$ and $16.78 \%$ respectively. On the other hand, water consumption has been increased significantly due to the Meknes city growth, the arboriculture expansion and the new crops' introduction in the arable areas. The increased water consumption by human activities is largely due to reduced water losses through evapotranspiration because of deforestation. Since the major part of the forest in the catchment has disappeared, a further increase of the water consumption by human activities can no longer be offset by deforestation.
\end{abstract}

Keywords: Boufakrane river watershed; remote sensing; LULCC; water balances 


\section{Introduction}

Worldwide, freshwater consumption is increasing due to population growth and livelihoods and land use change. The total volume of water is estimated at about 1.4 billion $\mathrm{km}^{3}$. Only $2.5 \%$ of this volume ( 35 million $\mathrm{km}^{3}$ ) can be considered as fresh water, with an unequal distribution [1]. Moreover, about $66 \%$ of the world population suffers from water scarcity [1]. Therefore, water is considered as a major challenge both as a resource and as a risk.

The Mediterranean is one of the most affected regions by water scarcity because of several factors including, extreme natural inter-annual variability, seasonality of water resources and decreasing stream flows forecast in coming decades [2]. Identified as a climate change "hot spot" [3], the Mediterranean area experiences severe episodic droughts, and has a high anthropogenic demand for surface and ground water [4,5]. Unfortunately, in most Mediterranean countries, where water demand is expected to increase significantly due to population growth, agricultural development and scarcity of water resources, could lead to poverty for millions of people [1], and influencing socio-economic development [6-8]. Therefore, water availability has been one of the most important environmental scientific research [9-11] to assess and develop adequate adaptation strategies.

Land use land cover changes refer to the modification of the Earth's surface by human activities [12]. Recently with the development of space technology, remote sensing integrating with GIS has become an effective tool for mapping and spatial-temporal monitoring of land use change [13-19], it provides a detailed understanding of the different functioning of ecosystems [20-25]. Therefore these techniques show a strong interest in deriving information about the Earth's surface, both in space and time [26,27]. Around the world, several studies have been carried out with the aim of studying land use changes through satellite image processing tools in different climatic contexts [28-32], and especially in semi-arid areas $[14,16,33]$. Understanding the relationship between the biosphere aspects of the hydrological cycle (BAHC) and the land use and land cover changes has been taken as the core plan of the International Geosphere-Biosphere Program (IGBP) and the International Human Dimension Program (IHDP) [34]. Additionally, understanding the impact of land use/land cover (LULC) changes on hydrological process is considered as one core problem in the LUCC research areas established by IGBP and IHDP. In this sense, many authors made several efforts to understand and evaluate the hydrological responses to different LULC patterns' changes. For example, Woldesenbet, Tekalegn Ayele et al., [35], based on an integrated approach of hydrological modeling and partial least squares regression (PLSR), quantified the contributions of changes in individual LULC classes to changes in hydrological components with application in two watersheds, namely Lake Tana and Beles in the Upper Blue Nile Basin in Ethiopia.

Van Ty, Tran et al., [36] applied an interdisciplinary scenario analysis approach to assess the potential impacts of climate, land use/cover and population changes on future water availability and demand in the Srepok River basin, a trans-boundary basin. They found that surface runoff will be increased with increased future rainfall and concluded that LULC change is found to have the largest impact on increased water demand, and thus reduced future water availability. Li, Zhihui et al., [37] studied the impacts of land use changes on surface runoff and water yield with scenario-based land use change in the upper and middle reaches of the Heihe River Basin. Their results showed an expansion of the forestland and grassland with the increase in water utilization ratio.

In Morocco, the challenges of water scarcity, harsh climatic conditions, population growth, intense urbanization and socio-economic development issues, considerable efforts are made to a wiser water resources use. In addition, the uneven spatiotemporal distribution of rainfall and water resources requires the implementation of an optimal management system of these scarce resources, and to relieve the pressure exerted on it.

Given this context, the specific objectives were: (i) to study the land use/land cover changes in the Boufakrane river watershed; (ii) to quantify the water availability and demand and (iii) to establish the relationship between land use/land cover, and water availability.

To the best of our knowledge, this paper presents the first detailed study using a combination of remote sensing and reference data to explore the relationship between landscape dynamics, 
water availability, and consumption in this study area. Analyzing water demand using satellites data as prevention, warning, monitoring and modeling tools, is of crucial importance for an effective control of water consumption over the Boufakrane river watershed.

\section{Materials and Methods}

\subsection{Study Area}

The study area is the Boufakrane river watershed, which is located in Meknes region in Morocco, between longitudes $6^{\circ} 0^{\prime} 00^{\prime \prime}$ and $6^{\circ} 6^{\circ} 15^{\prime} 00^{\prime \prime} \mathrm{S}$ and latitudes $37^{\circ} 00^{\prime} 00^{\prime \prime}$ and $37^{\circ} 45^{\prime} 00^{\prime \prime} \mathrm{N}$ (Figure 1). The study site total area is of nearly 39,948 ha. It crosses the western part of the plain of Saïss, bounded to the South by the Middle Atlas mountain range, to the North by the Pre-Rif wrinkles, and to the West by the Beht river and its Paleozoic outcrops that is made from the Western Meseta. The topographical rating decreases from South to North and ranges from 1383 to $277 \mathrm{~m}$. Geologically, the basin includes various formations stretching from the Paleozoic to the Quaternary, the majority of which are lacustrine limestone and fauves of the Plio-Quaternary sand [38].

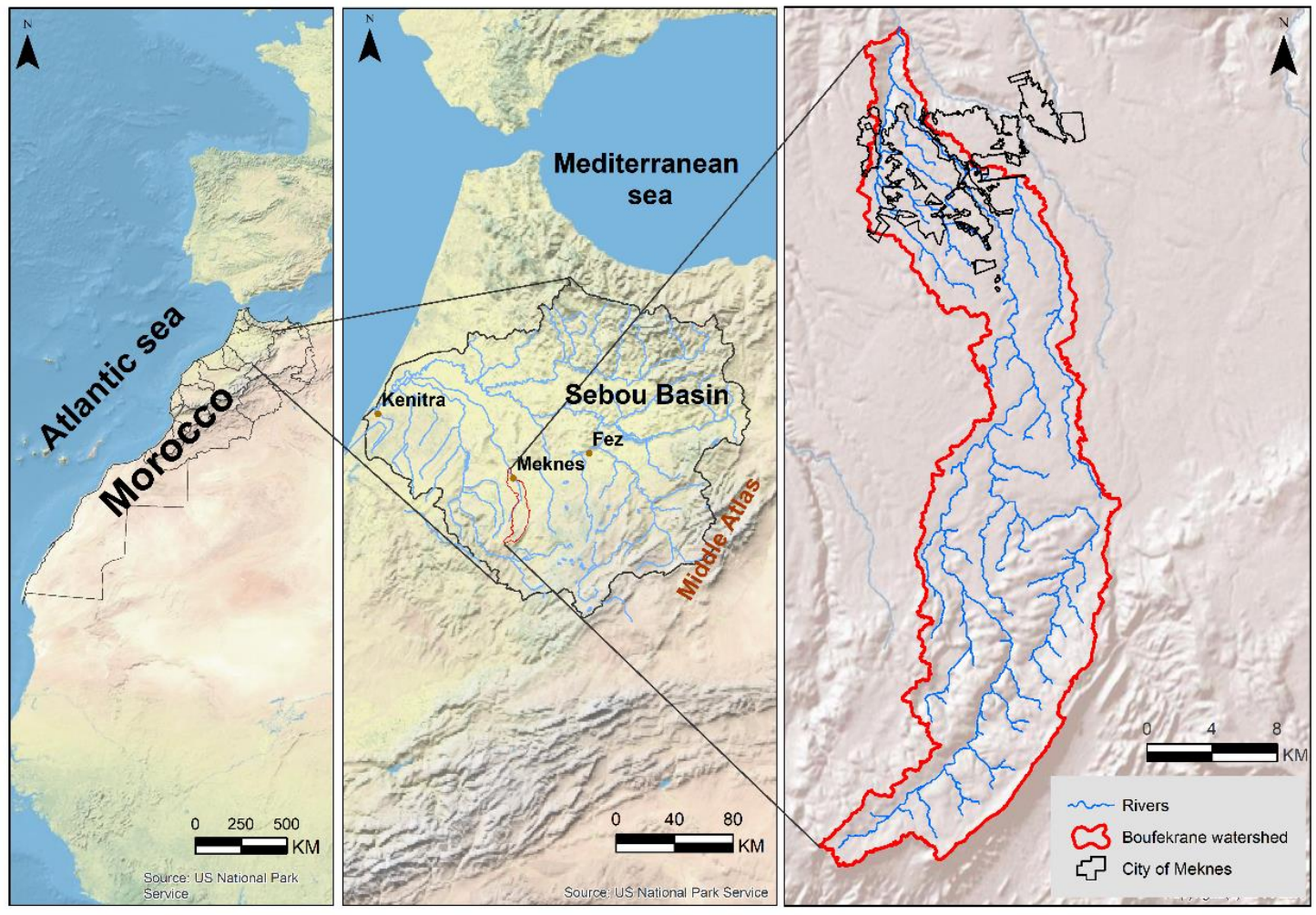

Figure 1. Study Area.

From the climatic point of view, the selected study area is characterized by a semi-arid climate, with an average annual rainfall of $500 \mathrm{~mm}$ recorded in the Meknes station, and a dry season extending from June to October. The area is experiencing very important economic activity, consisting of agriculture (olive groves, arboriculture, cereal farming and legumes). It is characterized by very important agricultural activities with an acceptable soil quality and a very large amount of water resources. Recently, the management of these water resources is no longer sustainable due to the overexploitation of water resources. The latter, is mainly induced by the population growth, the development of industry and agricultural activities, and the urban extension at the expense of the agricultural areas. At the downstream of the Boufakrane river watershed, the city of Meknes-one of the largest cities of Morocco with a very high population density-is located. According to the national census of 2014, its population is estimated at 630,079 inhabitants [39]. This city is known 
for its historical riches, its mosaic culture and its considerable economic potential in the agricultural, industrial, touristic and commercial fields.

\subsection{Methodology}

The data used in this work is composed of three Landsat images including Thematic Mapper (TM), Enhanced Thematic Mapper Plus (ETM+) and Operational Land Imager (OLI) of the years 1990 (TM), 2003 (ETM+) and 2018 (OLI). The images were radiometrically corrected (Figure 2). Images were used to identify six main land cover types-built-up areas, natural vegetation, cereals and agricultural bare soil, arboriculture, forest and bare soil-using a maximum likelihood classification. More detailed explanations about this classification algorithm can be found in the literature [40-42]. All images were captured in July in order to avoid the misclassification between agriculture area and soil bare area. Sixty-three points were taken during the sampling campaign conducted in many parts of the study area during May 2018 to validate the classification results (Figure 3). The evaluation of the classification accuracy is achieved by comparing the obtained classes using the classification algorithm to known classes at sampled reference locations. These collected data are further characterized in a confusion matrix $[43,44]$. The kappa index was used to measure the concordance between the field truth points and the different classification outputs. The values of this index are ranked from 0 to 1 , where 0 indicates a no concordance, and 1 is a significance of a perfect concordance [45,46]. For the next steps of the methodology applied in this work, the information about the water consumption, water demand and the population of the city of Meknes were obtained from several documents and reports including, census data and FAO reports [39,47,48], as well as crops' water consumption data [12,49].

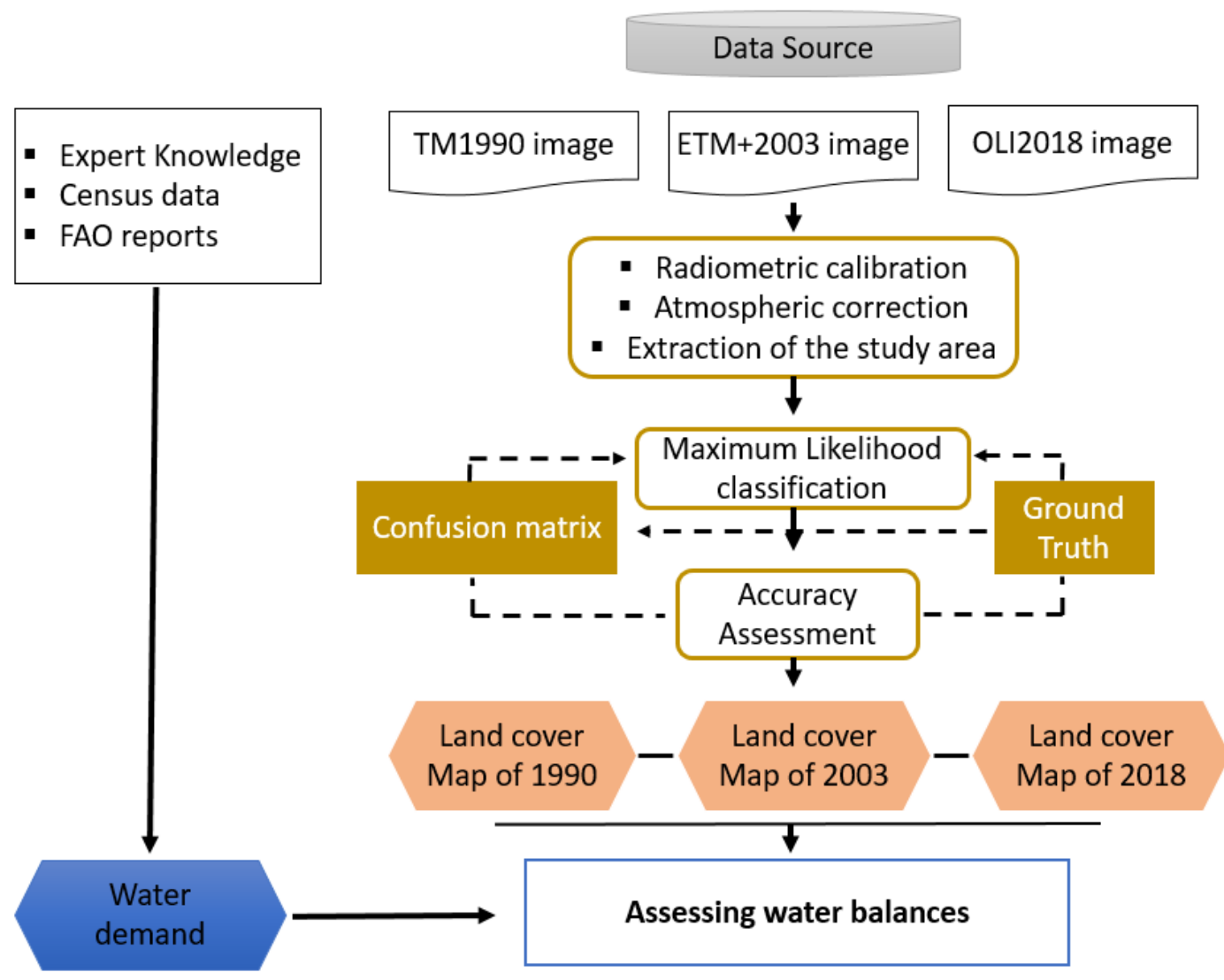

Figure 2. Flowchart of the implemented methodology. 


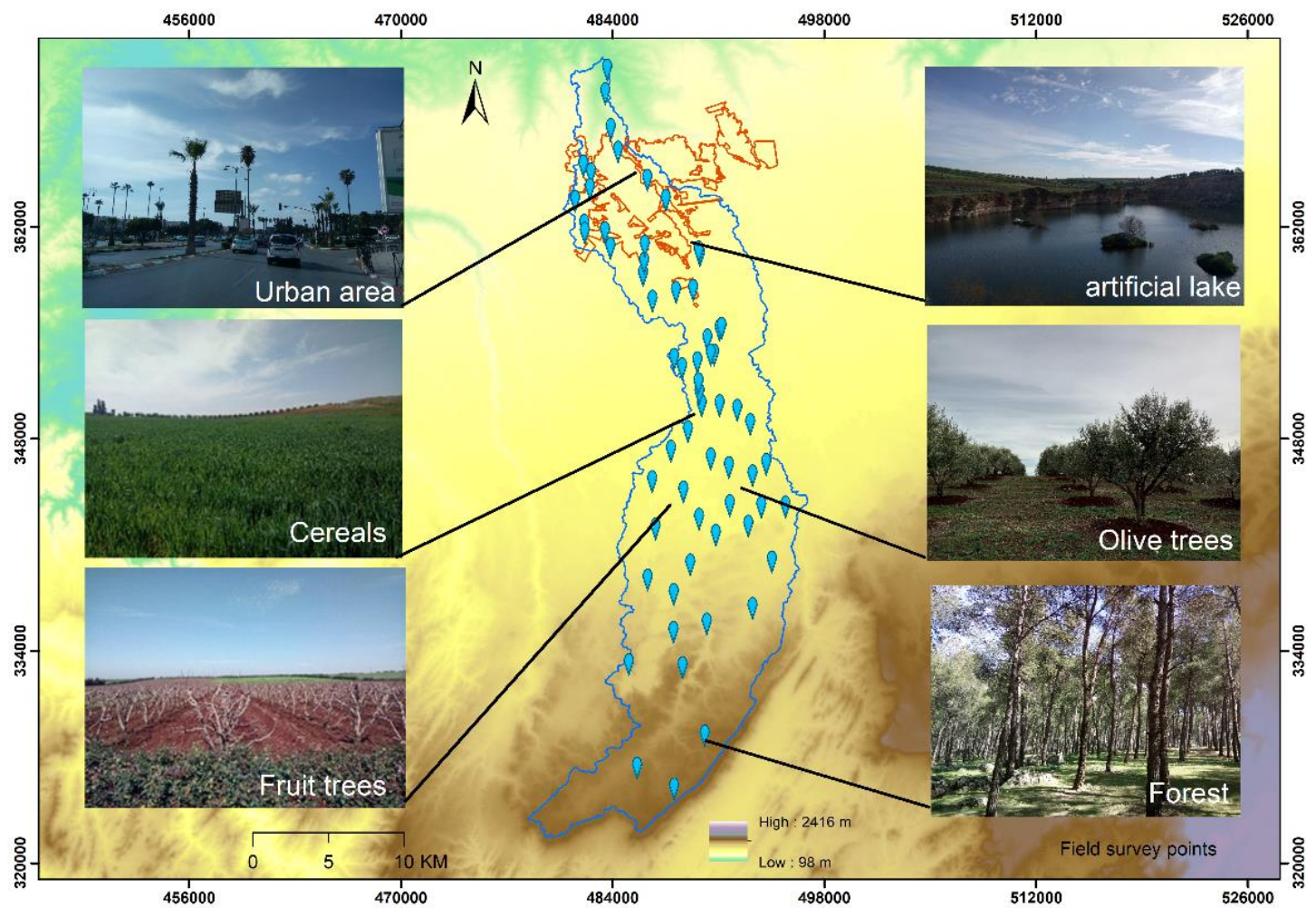

Figure 3. Field survey points.

\section{Results and Discussion}

\subsection{Land Use Land Cover Changes (LULCC)}

Land use/land cover changes (LULCC) were estimated during the period 1990-2018 using the supervised classification and based on multi-date images (Table 1, Figure 4). Cereal and agricultural bare soil, arboriculture and urban areas were increased respectively by $48 \%, 34 \%$ and $183 \%$, whereas the forest has decreased by $78 \%$ over the same period (Table 1 ). The increase in the agricultural areas (cereals and arboriculture areas) is illustrated in the agricultural development that the region has known, as well as the integration of new technologies in this area, with the new subsidies that the State has provided to farmers within the framework of the Moroccan Green Plan [50].

These results confirm the evolution of agriculture in Morocco, according to the Moroccan Agriculture Ministry statistics, the areas of olive groves in Morocco increased from 251,061 ha to 397,178 ha during the period 2001-2018 for irrigated areas, and from 374,146 ha to 676,314 ha for rain-fed areas, during the same period with an overall yield of 1,912,237 Tons in 2018 for all the country. For cereals class, the areas decreased from 4,826,100 ha in 2001 to 4,486,778 ha in 2018 for both rain-fed and irrigated ones. While production increased from 4,471,530 tons to 10,261,554 tons during the same period [51].

In terms of urbanization, the city of Meknes showed an increase by three times in the period 1990-2018, with a rate of $183 \%$ (Table 1). The results showed a strong spread of construction in this period, while the surface of the city has tripled from 25 to $73 \mathrm{~km}^{2}$.

In Meknes, the majority of urban growth occurred in the city's surroundings and it is generally, presented in the economic housing category that recently has met the needs of the population. According to the classification results, the evolution was generally noted in the South and the North-East where the landscape is characterized by a very low relief, unlike the wrinkly Northern part of the city, which has remained almost stable throughout this period. 
Table 1. Area change in different land use/land cover (LULC) categories from 1990 to 2018.

\begin{tabular}{ccccccc}
\hline & \multirow{2}{*}{$\begin{array}{c}\text { Area 1990 } \\
\text { (ha) }\end{array}$} & $\begin{array}{c}\text { Area 2003 } \\
\text { (ha) }\end{array}$ & Area 2018 & \multicolumn{2}{c}{ Chang 1990-2018 } \\
\cline { 5 - 7 } & & & & (ha) & (ha) & (\%) \\
\hline Built-up area & 2577 & 3758 & 7314 & +4736 & +183 \\
Natural vegetation & 941 & 1022 & 1059 & +118 & +12 \\
Cereals and agricultural bare soil & 9720 & 11,420 & 14,262 & +4541 & +48 \\
Arboriculture & 5733 & 6707 & 7740 & +2006 & +34 & -78 \\
Forest & 7026 & 3026 & 1500 & -5526 & -16 \\
Bare soil & 16,217 & 14,535 & 13,499 & -2718 & -16 \\
\hline
\end{tabular}
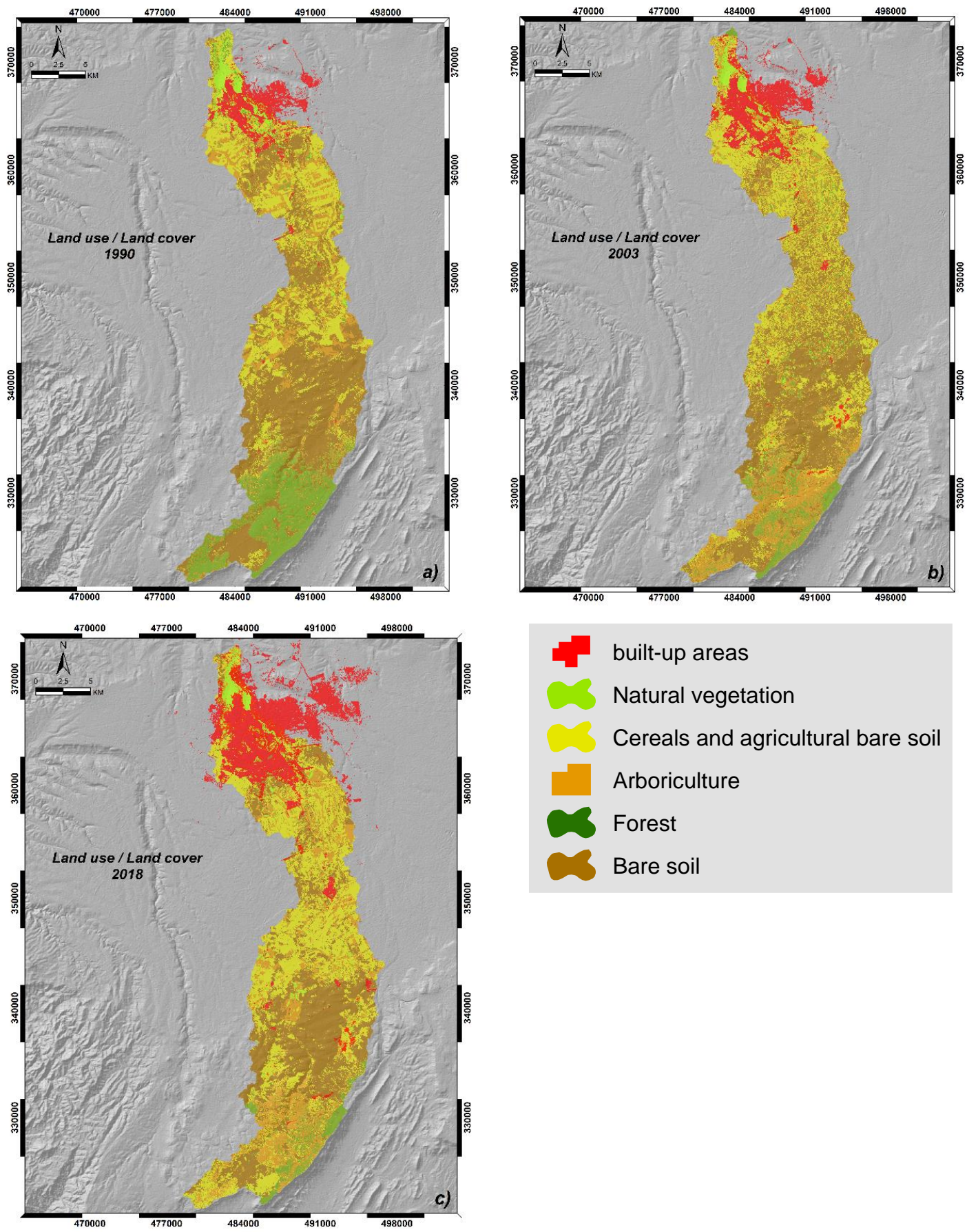

built-up areas

Natural vegetation

Cereals and agricultural bare soil

Arboriculture

Forest

Bare soil

Figure 4. LULC map, (a) LULC map for 1990, (b) LULC map for 2003 and (c) LULC map for 2018. 


\subsection{Overall Accuracy}

The evaluation of accuracy of LULC classification was made by ground-truth points collected from reference data including field survey data, and high-resolution images from Google Earth, and by using the confusion matrix. The results show an overall accuracy of $67.55 \%, 70.37 \%$ and $87.59 \%$, respectively in 1990, 2003 and 2018, whereas the kappa index is 0.56, 0.56 and 0.83 , respectively (Table 2). The classification of 2018 showed a perfect agreement, while those of 1990 and 2003 showed moderate agreement.

Regarding the confusion matrix, the validation of the classification by field data shows confusion between a few classes, such as: arboriculture, cereals and agriculture bare soil and bare soil. This is essentially due to the similar spectral response between cereals and arboricultural areas (Figure 5), as well as the leaf area of a tree, per unit of soil area or pixel unit.

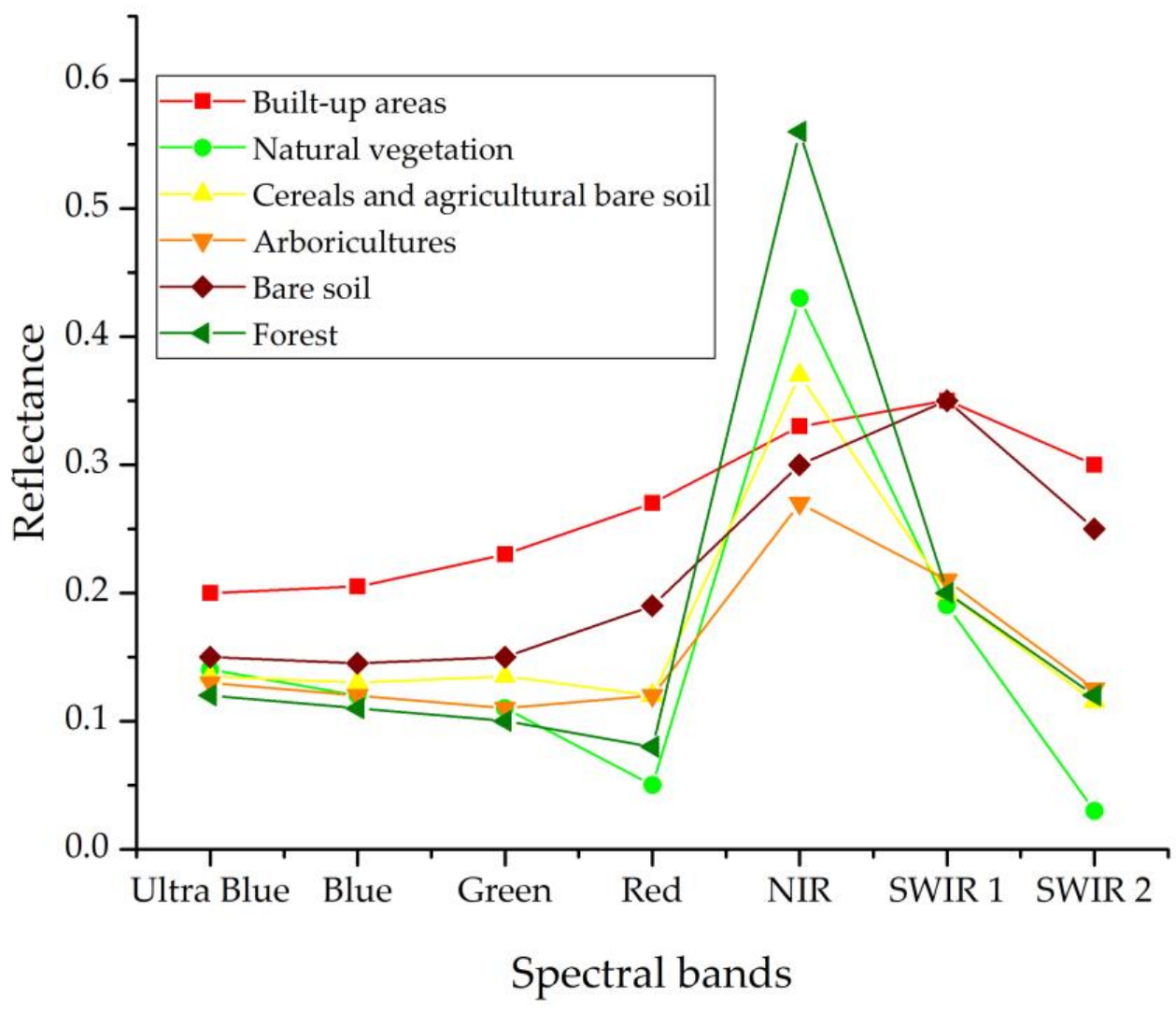

Figure 5. Spectral profiles of different classes.

In Table 2, a classification confusion matrix for the image captured in 1990 was presented. The overall accuracy of this classification was $67.55 \%$, and its kappa index was 0.56 . It showed that there was confusion during the classification process. For example, $28.16 \%$ of the points sampled in cereals and agricultural bare soil were classified as arboriculture areas, and $11.87 \%$ as bare soil areas. The same is shown in the other two time periods (2003 and 2018), but with a decrease observed in term of confusion. Conversely, the classification showed a strong performance in mapping urban area by clearly distinguishing it from the other LULC classes. Results show that the classification accuracy of sampled urban areas was $99.00 \%, 96.01 \%$ and 96.18 for 2018, 2003 and 1990 respectively. 
Table 2. Confusion matrix for the three times (1990, 2003 and 2018).

\begin{tabular}{|c|c|c|c|c|c|c|c|c|c|c|c|c|c|c|c|c|c|c|c|c|c|}
\hline \multirow{3}{*}{$\begin{array}{l}\text { Class } \\
\text { Year }\end{array}$} & \multicolumn{18}{|c|}{ Ground Truth (\%) } & \multicolumn{3}{|c|}{ Total (\%) } \\
\hline & \multicolumn{3}{|c|}{$\begin{array}{c}\text { Cereals and Agricultural } \\
\text { Bare Soil }\end{array}$} & \multicolumn{3}{|c|}{ Arboriculture } & \multicolumn{3}{|c|}{ Forest } & \multicolumn{3}{|c|}{ Urban Area } & \multicolumn{3}{|c|}{ Bare Soil } & \multicolumn{3}{|c|}{ Natural Vegetation } & \multirow[b]{2}{*}{1990} & \multirow[b]{2}{*}{2003} & \multirow[b]{2}{*}{2018} \\
\hline & 1990 & 2003 & 2018 & 1990 & 2003 & 2018 & 1990 & 2003 & 2018 & 1990 & 2003 & 2018 & 1990 & 2003 & 2018 & 1990 & 2003 & 2018 & & & \\
\hline Cereals and agricultural bare soil & 57.83 & 76.45 & 82.14 & 19.57 & 19.57 & 2.46 & 1.95 & 0 & 0.19 & 0.52 & 0.78 & 0.56 & 17 & 21.63 & 7.77 & 0.26 & 0 & 0 & 30.67 & 40.06 & 30.67 \\
\hline Arboriculture & 28.16 & 4.74 & 7.7 & 55 & 26.24 & 86.26 & 9.53 & 11.09 & 27.63 & 3.3 & 2.86 & 0.15 & 1.61 & 1.94 & 0.33 & 0.77 & 1.02 & 8.18 & 19.42 & 6.83 & 19.42 \\
\hline Forest & 2.13 & 1.31 & 0.59 & 4.51 & 18.85 & 0.03 & 81.13 & 88.91 & 72.18 & 0.67 & 0 & 0.11 & 0.98 & 0.48 & 0.36 & 2.3 & 5.12 & 0 & 3.74 & 5.61 & 3.74 \\
\hline Urban area & 0 & 0.09 & 0.59 & 0.42 & 0.09 & 0.03 & 0 & 0 & 0 & 96.18 & 96.01 & 99 & 0.05 & 0.01 & 0 & 0 & 0 & 0 & 5.04 & 5.02 & 5.04 \\
\hline Bare soil & 11.87 & 16.76 & 8.63 & 16.17 & 21.16 & 1.2 & 7.39 & 0 & 0 & 0 & 0 & 0.19 & 80.36 & 75.94 & 91.55 & 0 & 0 & 0 & 38.79 & 39.38 & 38.79 \\
\hline Natural vegetation & 0.01 & 0.61 & 0.64 & 4.33 & 8.21 & 10.01 & 0 & 0 & 0 & 0 & 0.35 & 0 & 0 & 0 & 0 & 96.88 & 93.86 & 91.82 & 2.34 & 3.1 & 2.34 \\
\hline
\end{tabular}




\subsection{Urban Growth of Meknes City 1990-2018}

This part was developed generally to have an idea about urbanization trends in the city of Meknes. The results show a very important urban expansion, generally in the areas surrounding the city (Figure 6). The "Cities without slums" program that was launched in Morocco in 2004 has made significant progress in reducing slums initially targeted and improving housing conditions for low-income households [48]. This ambitious governmental strategy resulted in in-depth revision of public housing policies, opening of new construction sites, reforms and the definition of innovative and proactive programs able to respond, a more appropriate way of social housing promotion, eliminating and preventing of insalubrious housing and anticipation of urban development. About 26 projects with 44,400 dwellings on a surface of 822 ha, were authorized between 2008 and 2012, and subsequent constructions had even exceeded the population needs [48].

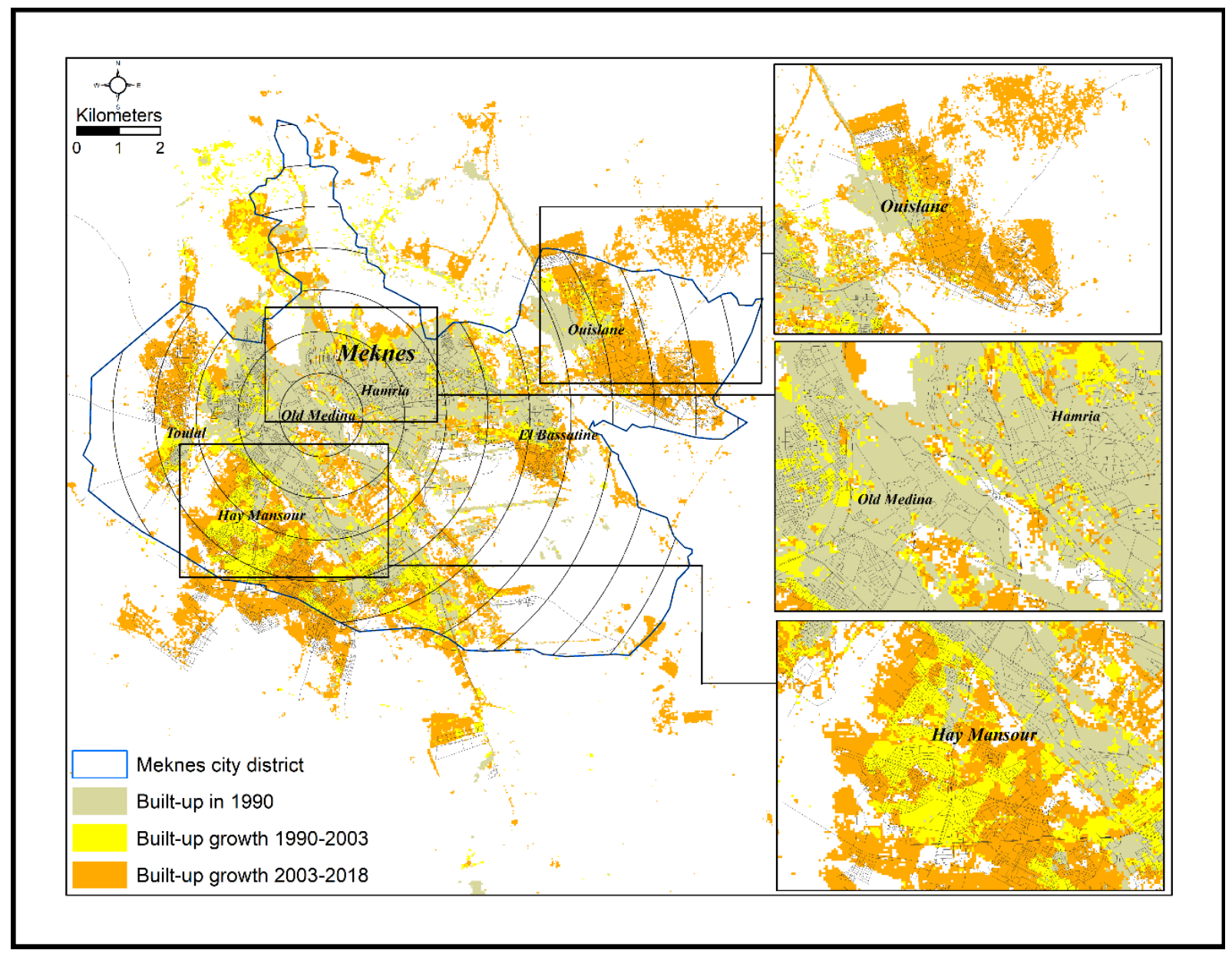

Figure 6. Observed urban expansion between 1990 and 2018 in Meknes city.

Historically speaking, about 1590 ha of agricultural areas in Boufakrane river watershed were transformed into urban areas during the last 30 years. This can be explained by the socio-economic boom of the city of Meknes combined to the improvement of infrastructure, the population and urbanization growth, the medical care networks, the communication, transport and mobility facilities. Furthermore, the industrialization and the installation of various economic activities in its edge designed the immigration flow from the surrounding areas.

Meknes city agglomeration is comprised of clearly individualized urban units, which are namely: the old Medina, the imperial city, the new city and the recent urban expansions. Each of them is related to a specific historical period. 
Historically, Meknes city experienced the apparition of new established neighborhoods in its surroundings especially in the South-Western and the North-Eastern parts such as, Hay Mansour (Figure 6). Unfortunately, these areas correspond to very fertile agricultural soils (Saïss plain) are affected and will continue to be so in the upcoming years by various urban development projects.

\subsection{Water Availability and Water Demand}

Based on the latest United Nations statistics, Morocco is characterized by a very high human potential with a total population of $36,465,862$ dwellers with a median age of 28.3 years. The percentage of the urban population is estimated to $60.3 \%\left(22,093,561\right.$ people in 2019), in a total area of $446,300 \mathrm{Km}^{2}$. According to the last Moroccan census conducted in 2014, the population of the city of Meknes; including its municipalities, Al Machouar, Ouislane and Toulal, increased by $25.4 \%$, from 471,908 inhabitants to 632,079 inhabitants during the period 1990-2014 [39]. Therefore as the population grew, the water demand has increased in Meknes, from 19.30 to 29.8 million $\mathrm{m}^{3}$ during the same period (Figure 7). So far, the changes that occurred in the land use of the Boufakrane river watershed and the increase in agricultural areas (cereals and arboriculture) resulted in an increase in the water demand during the same period from 91.92 million to 96.12 million $\mathrm{m}^{3}$. Projected data shows that the water demand for the population, cereals and tree crops will increase, respectively by $8.54 \%, 16 \%$ and $10.68 \%$, with a global increase of $8.82 \%$ (Figure 7), and consequently water demand will be of $104.27 \mathrm{Mm}^{3}$ in 2030 . Thus, with this alarming situation and unsustainable management of this resource, many problems will be encountered in terms of water availability.

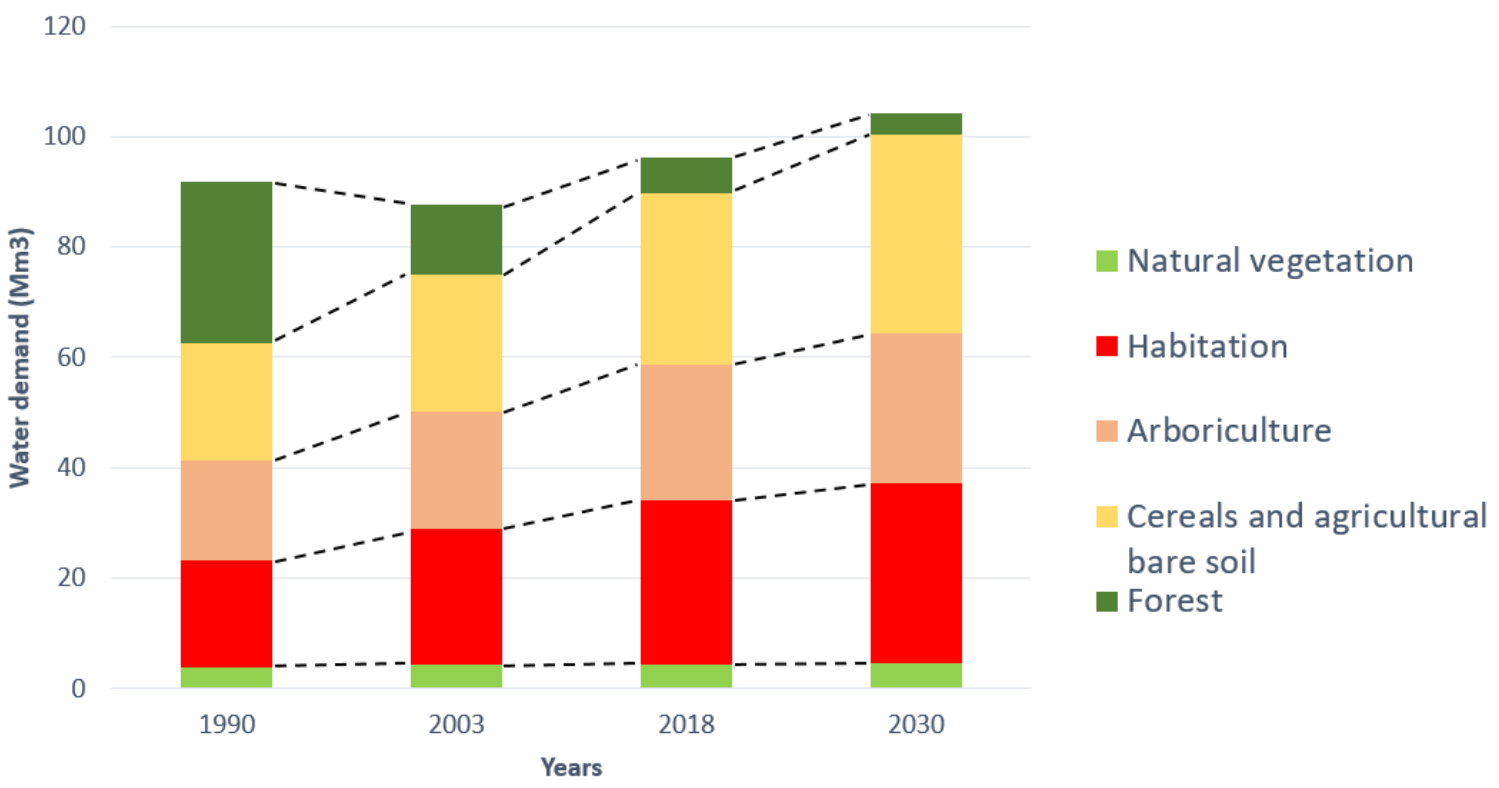

Figure 7. Water demand for different classes.

At the same time, groundwater resources are also affected by this change. Even with the large quantity of water stored in the aquifer system of this watershed, the piezometric history of the aquifer shows a general decline with about $1 \mathrm{~m} /$ year in average (Figure 8). As a result, during the last 30 years, this level has declined by almost $20 \mathrm{~m}$. This has led to the disappearance of this groundwater in some places, and consequently to the transformation of the agricultural system from an irrigated system to a rain-fed system. 


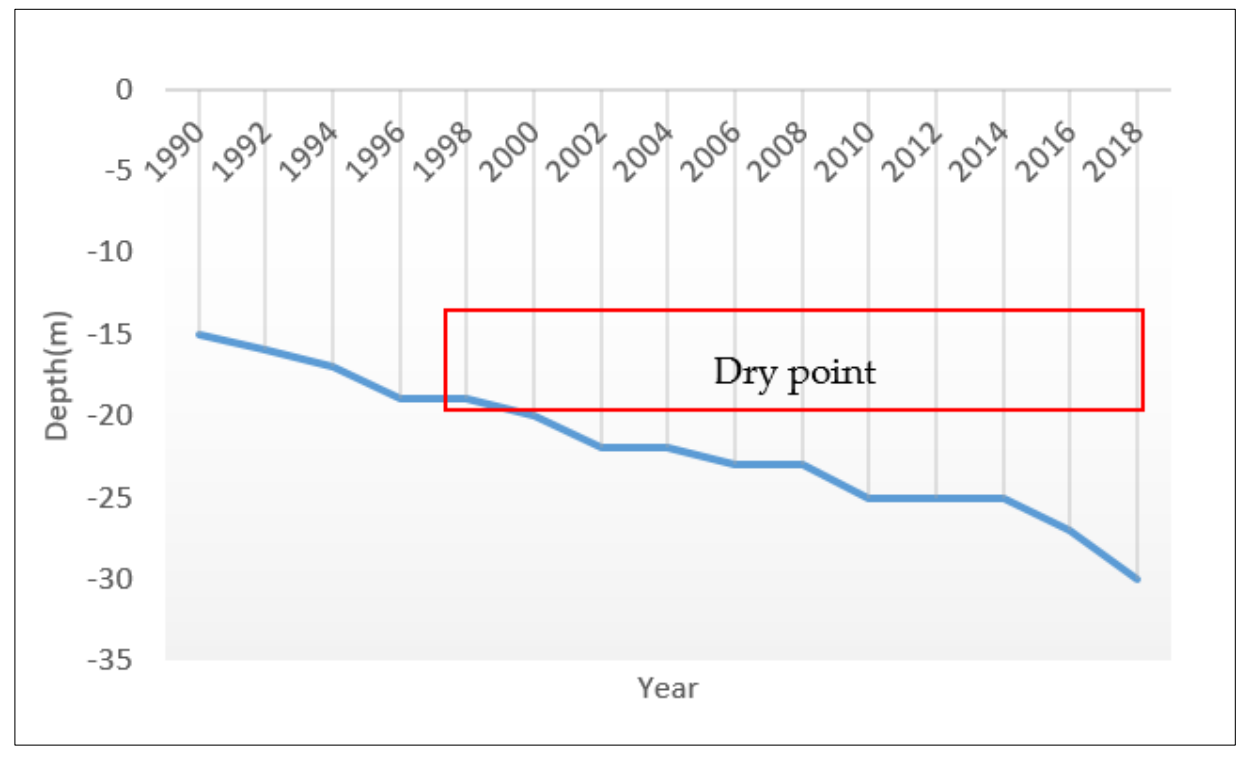

Figure 8. Depth of the water table piezometric surface.

In this situation, it is mandatory to set up a sustainable management system, including the intervention of the various stakeholders in the region. To find solutions and re-orient the usage of this resource in the right path by implementing an irrigation system adapted to the available amount of water, and to adopt more smart cropping systems fitting to the local context.

In terms of urban demography, this sector has known an enormous evolution, especially the city of Meknes in the downstream part of the watershed. This is generally due to several reasons, including; the industrialization and the installation of diverse economic activities in the peripheries of the city, the development and the improvement of transport network and mobility, as well as the enhancement of the life quality in the city with the availability of medical and communication services, and infrastructure development. This development had an effect on water consumption in the city. Yet, according to the local water and electricity distribution agency [52], for 2018, the consumed amount of water in the city is about 30.28 million $\mathrm{m}^{3}$ with an increase of $58 \%$ during the same period. With a total number of 180,609 , the consumers are largely private consumers while only 715 of them are big consumers and 969 are local governments, organizations and communities.

\subsection{Results' Interpretation}

The combination of satellite image processing techniques, surveys and field data to study the relationship of land use change and its relation to water availability, demand and consumption has been very effective in assessing water balances at the regional scale. In particular, the classification used in this work showed a high degree of accuracy, and clearly described the different changes in the study area during the last 28 years. Furthermore, the combination of satellite and field data allows us to assess the water balances in the Boufakrane river watershed.

Throughout the literature analysis, for several works about the same research topic, remote sensing has shown a strong performance in the study of land use/cover changes $[14,16]$, the development and generation of land-use change scenarios for hydrological modeling [53] and urban dynamics [29,54-56]. For example, Ashraf M. Dewan et al. [29] studied land-use changes in Greater Dhaka, Bangladesh for a period of 28 years, based on remote sensing images to promote sustainable urbanization. They found that the Dhaka region had experienced rapid changes in land use, particularly in the urban area.

In a related context, A. El Garouani et al. [57] carried out a study to understand the relationship between urbanization and land use/land cover changes and their impacts on the urban landscape during the period 1984-2013 in the Fez region, Morocco. The results showed a strong performance of 
the classification with an overall accuracy ranging from $78 \%$ to $87 \%$. In terms of land use, the urban area increased with $121 \%$, whereas agriculture and forests decreased with $11 \%$ and $3 \%$ respectively.

Additionally, previous studies have been carried out, aimed at using geospatial tools for spatio-temporal monitoring of land use/land cover changes in areas with similar landscape. For example C. Höpfner and D. Scherer [58], has used this technique to analyze the spatio-temporal dynamics of land use and vegetation in north-west Morocco. The approach showed that with this technique, it is possible to derive conclusions about land-use dynamics in a largely unknown region with ground truth knowledge. While the validation was very powerful, it showed $80.24 \%$ overall accuracy, and a Kappa coefficient of 0.74 .

In fact, the method used in this work is a temptation to link satellite and field data for the evaluation of the water balance. After the calculation of the different classes' surfaces extracted by the supervised classification. The water demand for each class is estimated based on field surveys with farmers, reports from the Regional Directorate of Agriculture, and the reports from the Food and Agriculture Organization (FAO). Concerning water demand for the population, the demand was estimated based on reports from the Meknes Water Distribution Agency.

\section{Conclusions}

In this study, a methodology of land use/land cover changes, availability and water demand based on the Landsat satellites images and field data in the Boufakrane river watershed is presented. It aims to link the image processing approach and water demand analysis. The classification used in this work has been very effective in improving land use changes that the region has experienced, and it showed high accuracy. The results showed that urban areas, natural vegetation, arboriculture and cereals increased by $183.74 \%, 12.55 \%, 34.99$ and $48.77 \%$ respectively while forests and bare soils decreased by $78.65 \%$ and $16.78 \%$ respectively. However, the development of agriculture had an effect on water demand, since it increased by $4.56 \%$, from 91.92 million to 96.12 million $\mathrm{m}^{3}$ in the same period. Projected data showed that water demand will increase by $8.82 \%$ with $104.27 \mathrm{Mm}^{3}$ in 2030 , which will create in the near future many problems in term of water availability, which requires intervention from all water stakeholders in the region as well as policy makers to find real solutions for sustainable management. The fully adopted methodology used in this research topic was based on free data and open source software, which can be applied to other areas to generate the same output based on the same approach. Moreover, this work represents new approaches to be urgently adopted in the region, and presents a strong base for that. This was possible by depicting the land use/land cover changes experienced by the region in the last 30 years then by providing accurate information on the management of water resources system in the region. To sum up, this research can be of valuable contribution in decision-making regarding the planning and the implementation of sustainable agricultural policies, and the elaboration of strategies for efficient and sustainable integrated water resources management. It can be also useful for assessing water balances taking into account the land use/land cover changes and its relationship with water demand. Ultimately, the developed approach can be of precious usefulness in other areas with similar background.

Author Contributions: Conceptualization, M.E.H., A.E. and A.V.R.; Data curation, M.E.H.; Formal analysis, M.E.H., A.E. and A.V.R.; Methodology, M.E.H., A.E. and A.V.R.; Project administration, A.E. and A.V.R.; Resources, A.E.H., A.E.O., N.-E.S. and F.M.; Software, M.E.H.; Supervision, A.E. and A.V.R.; Validation, M.E.H., A.E. and A.V.R.; Visualization, M.E.H.; Writing-original draft, M.E.H.; Writing—review \& editing, M.E.H., A.E., A.V.R., M.M. and F.M. All authors have read and agreed to the published version of the manuscript.

Funding: This research received no external funding.

Acknowledgments: The authors acknowledge the financial support of VLIR-UOS for the help of the equipment and missions at the KU Leuven, Belgium. Thanks are also due to the anonymous reviewers for their valuable comments on this article, which allowed us to improve the scientific quality of this research.

Conflicts of Interest: The authors declare that they have no conflict of interest. 


\section{References}

1. Cuenca, J.C.; de Murcia, R.; del Campo García, A.; España, D.R.M. Euro-Mediterranean Information System on Know How in the Water Sector. Available online: https://www.riob.org/fr/node/3071 (accessed on 18 January 2020).

2. Martinez, M.G.; Poole, N. The development of private fresh produce safety standards: Implications for developing Mediterranean exporting countries. Food Policy 2004, 29, 229-255. [CrossRef]

3. Cramer, W.; Guiot, J.; Fader, M.; Garrabou, J.; Gattuso, J.P.; Iglesias, A.; Lange, M.A.; Lionello, P.; Llasat, M.C.; $\mathrm{Paz}, \mathrm{S}$.; et al. Climate change and interconnected risks to sustainable development in the Mediterranean. Nat. Clim. Chang. 2018, 8, 972-980. [CrossRef]

4. Anderson, R.G.; Jin, Y.; Goulden, M.L. Assessing regional evapotranspiration and water balance across a Mediterranean montane climate gradient. Agric. For. Meteorol. 2012, 166, 10-22. [CrossRef]

5. Bolle, H.-J. Climate, climate variability, and impacts in the Mediterranean area: An overview. In Mediterranean Climate; Springer: Berlin/Heidelberg, Germany, 2003; pp. 5-86.

6. Ouatiki,H.; Boudhar, A.; Tramblay, Y.; Jarlan, L.; Benabdelouhab, T.; Hanich, L.; El Meslouhi, M.; Chehbouni, A. Evaluation of TRMM 3B42 v7 rainfall product over the Oum Er Rbia watershed in Morocco. Climate 2017, 5, 1. [CrossRef]

7. Schilling, J.; Freier, K.P.; Hertig, E.; Scheffran, J. Climate change, vulnerability and adaptation in North Africa with focus on Morocco. Agric. Ecosyst. Environ. 2012, 156, 12-26. [CrossRef]

8. Jellali, M.M. Développement des ressources en eau au Maroc. In Aspects Économiques de la Gestion de l'Eau dans le Bassin Méditerranéen; CIHEAM: Bari, Italy, 1997; pp. 51-68.

9. Giorgi, F.; Lionello, P. Climate change projections for the Mediterranean region. Glob. Planet. Chang. 2008, 63, 90-104. [CrossRef]

10. Marcè, R.; RODRÍGUEZ-ARIAS, M.À.; García, J.C.; Armengol, J.O.A.N. El Niño Southern Oscillation and climate trends impact reservoir water quality. Glob. Chang. Biol. 2010, 16, 2857-2865. [CrossRef]

11. Rivas-Tabares, D.; Tarquis, A.M.; Willaarts, B.; De Miguel, Á. An accurate evaluation of water availability in sub-arid Mediterranean watersheds through SWAT: Cega-Eresma-Adaja. Agric. Water Manag. 2019, 212, 211-225. [CrossRef]

12. FAO (Ed.) Forests and Agriculture: Land-Use Challenges and Opportunities; FAO: Rome, Italy, 2016.

13. Bakr, N.; Afifi, A.A. Quantifying land use/land cover change and its potential impact on rice production in the Northern Nile Delta, Egypt. Remote Sens. Appl. Soc. Environ. 2019, 13, 348-360. [CrossRef]

14. Barakat, A.; Ouargaf, Z.; Khellouk, R.; El Jazouli, A.; Touhami, F. Land use/land cover change and environmental impact assessment in béni-mellal district (Morocco) using remote sensing and gis. Earth Syst. Environ. 2019, 3, 113-125. [CrossRef]

15. Barakat, A.; Khellouk, R.; El Jazouli, A.; Touhami, F.; Nadem, S. Monitoring of forest cover dynamics in eastern area of Béni-Mellal Province using ASTER and Sentinel-2A multispectral data. Geol. Ecol. Landsc. 2018, 2, 203-215. [CrossRef]

16. El Jazouli, A.; Barakat, A.; Khellouk, R.; Rais, J.; El Baghdadi, M. Remote sensing and GIS techniques for prediction of land use land cover change effects on soil erosion in the high basin of the Oum Er Rbia River (Morocco). Remote Sens. Appl. Soc. Environ. 2019, 13, 361-374. [CrossRef]

17. Mohajane, M.; Essahlaoui, A.; Oudija, F.; El Hafyani, M.; Hmaidi, A.E.; El Ouali, A.; Randazzo, G.; Teodoro, A.C. Land Use/Land Cover (LULC) Using Landsat Data Series (MSS, TM, ETM+ and OLI) in Azrou Forest, in the Central Middle Atlas of Morocco. Environments 2018, 5, 131. [CrossRef]

18. Rogan, J.; Chen, D. Remote sensing technology for mapping and monitoring land-cover and land-use change. Prog. Plan. 2004, 61, 301-325. [CrossRef]

19. Wu, Q.; Li, H.Q.; Wang, R.S.; Paulussen, J.; He, Y.; Wang, M.; Wang, B.H.; Wang, Z. Monitoring and Predicting Land Use Change in Beijing Using Remote Sensing. Landsc. Urban Planing 2006, 78, 322-333. [CrossRef]

20. Balthazar, V.; Vanacker, V.; Molina, A.; Lambin, E.F. Impacts of forest cover change on ecosystem services in high Andean mountains. Ecol. Indic. 2015, 48, 63-75. [CrossRef]

21. Gerard, F.; Petit, S.; Smith, G.; Thomson, A.; Brown, N.; Manchester, S.; Wadsworth, R.; Bugar, G.; Halada, L.; Bezak, P.; et al. Land cover change in Europe between 1950 and 2000 determined employing aerial photography. Prog. Phys. Geogr. 2010, 34, 183-205. [CrossRef] 
22. Muttitanon, W.; Tripathi, N.K. Land use/land cover changes in the coastal zone of Ban Don Bay, Thailand using Landsat 5 TM data. Int. J. Remote Sens. 2005, 26, 2311-2323. [CrossRef]

23. Pervez, M.S.; Henebry, G.M. Assessing the impacts of climate and land use and land cover change on the freshwater availability in the Brahmaputra River basin. J. Hydrol. Reg. Stud. 2015, 3, 285-311. [CrossRef]

24. Essahlaoui, A.; Teodoro, A.C.; Mohajane, M. Modeling and mapping of soil salinity in Tafilalet plain (Morocco). Arab. J. Geosci. 2019, 12, 35.

25. Mohajane, M.; Essahlaoui, A.; Oudija, F.; El Hafyani, M.; Cláudia Teodoro, A. Mapping forest species in the central middle atlas of Morocco (Azrou Forest) through remote sensing techniques. ISPRS Int. J. Geo-Inf. 2017, 6, 275. [CrossRef]

26. Liang, D.; Zuo, Y.; Huang, L.; Zhao, J.; Teng, L.; Yang, F. Evaluation of the consistency of MODIS Land Cover Product (MCD12Q1) based on Chinese 30 m GlobeLand30 datasets: A case study in Anhui Province, China. ISPRS Int. J. Geo-Inf. 2015, 4, 2519-2541. [CrossRef]

27. Satyanarayana, B.; Thierry, B.; Seen, D.L.; Raman, A.V.; Muthusankar, G. Remote sensing in mangrove research-relationship between vegetation indices and dendrometric parameters: A Case for Coringa, East Coast of India. In Proceedings of the 22nd Asian Conference on Remote Sensing, Singapore, 5-9 November 2001; pp. 5-9.

28. Reis, S. Analyzing land use/land cover changes using remote sensing and GIS in Rize, North-East Turkey. Sensors 2008, 8, 6188-6202. [CrossRef] [PubMed]

29. Dewany, A.M. Yamaguchi, Land use and land cover change in Greater Dhaka, Bangladesh: Using remote sensing to promote sustainable urbanization. Appl. Geogr. 2009, 29, 390-401. [CrossRef]

30. Baldi, G.; Paruelo, J.M. Land-use and land cover dynamics in South American temperate grasslands. Ecol. Soc. 2008, 13, 6. [CrossRef]

31. Rawat, J.S.; Manish, K. Monitoring land use/cover change using remote sensing and GIS techniques: A case study of Hawalbagh block, district Almora, Uttarakhand, India. Egypt. J. Remote Sens. Space Sci. 2015, 18,77-84. [CrossRef]

32. Shalaby, A.; Tateishi, R. Remote sensing and GIS for mapping and monitoring land cover and land-use changes in the Northwestern coastal zone of Egypt. Appl. Geogr. 2007, 27, 28-41. [CrossRef]

33. Diouf, A.; Lambin, E.F. Monitoring land-cover changes in semi-arid regions: Remote sensing data and field observations in the Ferlo, Senegal. J. Arid Environ. 2001, 48, 129-148. [CrossRef]

34. Seitzinger, S.P.; Gaffney, O.; Brasseur, G.; Broadgate, W.; Ciais, P.; Claussen, M.; Erisman, J.W.; Kiefer, T.; Lancelot, C.; Monks, P.S.; et al. International Geosphere-Biosphere Programme and Earth system science: Three decades of co-evolution. Anthropocene 2015, 12, 3-16. [CrossRef]

35. Woldesenbet, T.A.; Elagib, N.A.; Ribbe, L.; Heinrich, J. Hydrological responses to land use/cover changes in the source region of the Upper Blue Nile Basin, Ethiopia. Sci. Total Environ. 2017, 575, 724-741. [CrossRef]

36. Van Ty, T.; Sunada, K.; Ichikawa, Y.; Oishi, S. Scenario-based impact assessment of land use/cover and climate changes on water resources and demand: A case study in the Srepok River Basin, Vietnam-Cambodia. Water Resour. Manag. 2012, 26, 1387-1407.

37. Li, Z.; Deng, X.; Wu, F.; Hasan, S. Scenario analysis for water resources in response to land use change in the middle and upper reaches of the Heihe River Basin. Sustainability 2015, 7, 3086-3108. [CrossRef]

38. Essahlaoui, A.; Sahbi, H.; Bahi, L.; El-Yamine, N. Reconnaissance de la structure géologique du bassin de Saiss occidental, Maroc, par sondages électriques. J. Afr. Earth Sci. 2001, 32, 777-789. [CrossRef]

39. Population Légale d'après les Résultats du RGPH 2014 sur le Bulletin Officiel $\mathrm{N}^{\circ}$. Available online: https://rgph2014.hcp.ma/downloads/Resultats-RGPH-2014_t18649.html (accessed on 18 January 2020).

40. Erbek, F.S.; Özkan, C.; Taberner, M. Comparison of maximum likelihood classification method with supervised artificial neural network algorithms for land use activities. Int. J. Remote Sens. 2004, 25, 1733-1748. [CrossRef]

41. Otukei, J.R.; Blaschke, T. Land cover change assessment using decision trees, support vector machines and maximum likelihood classification algorithms. Int. J. Appl. Earth Obs. Geoinf. 2010, 12, S27-S31. [CrossRef]

42. Paola, J.D.; Schowengerdt, R.A. A review and analysis of backpropagation neural networks for classification of remotely-sensed multi-spectral imagery. Int. J. Remote Sens. 1995, 16, 3033-3058. [CrossRef]

43. Lewis, H.G.; Brown, M. A generalized confusion matrix for assessing area estimates from remotely sensed data. Int. J. Remote Sens. 2001, 22, 3223-3235. [CrossRef]

44. Card, D.H. Using known map category marginal frequencies to improve estimates of thematic map accuracy. Photogramm. Eng. Remote Sens. 1982, 48, 431-439. 
45. Titus, K.; Mosher, J.A.; Williams, B.K. Chance-corrected classification for use in discriminant analysis: Ecological applications. Am. Midl. Nat. 1984, 111, 1-7. [CrossRef]

46. Bwangoy, J.R.B.; Hansen, M.C.; Roy, D.P.; De Grandi, G.; Justice, C.O. Wetland mapping in the Congo Basin using optical and radar remotely sensed data and derived topographical indices. Remote Sens. Environ. 2010, 114, 73-86. [CrossRef]

47. Agence Urbaine. Projet de Plan D'action de Développement Local Meknès; Meknès, Maroc, 2009. Available online: https://www.hcp.ma/region-meknes/attachment/428604/ (accessed on 18 January 2020).

48. Ministère Délègue Charge de l'Habitat et de l'Habitat et de l’Urbanisme, 2004, «Villes sans Bidonvilles». Available online: https://mirror.unhabitat.org/downloads/docs/11592_4_594598.pdf (accessed on 18 January 2020).

49. FAO. Food and Agricultural Organization of the United Nations FAO AQUASTAT Database; FAO: Rome, Italy, 2014; Available online: https://www.fao.orgnraquastat.pdf (accessed on 11 November 2018).

50. MAPM. Ministère de l'Agriculture et de la Pèche Maritime, Rapport Plan Maroc Vert; MAPM: Rabat, Morocco, May 2011.

51. Plan Bleu. Environnement et Développement en Méditerranée. Les Notes du Plan Bleu, No 11. 2009. Available online: https://planbleu.org/sites/default/files/publications/soed2009-fr.pdf (accessed on 18 January 2020).

52. Régie Autonome de Distribution d'Eau et d'Électricité de Meknès, Rapport de Gestion 2016 \& Comptes Annuels. Available online: https://www.radeema.ma/documents/56925/56948/RG2016+web.pdf/2bc8116b3429-459f-997a-783226946cbc (accessed on 18 January 2020).

53. Oñate-Valdivieso, F.; Sendra, J.B. Application of GIS and remote sensing techniques in generation of land use scenarios for hydrological modeling. J. Hydrol. 2010, 395, 256-263. [CrossRef]

54. Haque, M.M.; Egodawatta, P.; Rahman, A.; Goonetilleke, A. Assessing the significance of climate and community factors on urban water demand. Int. J. Sustain. Built Environ. 2015, 4, 222-230. [CrossRef]

55. Xiao, J.; Shen, Y.; Ge, J.; Tateishi, R.; Tang, C.; Liang, Y.; Huang, Z. Evaluating urban expansion and land use change in Shijiazhuang, China, by using GIS and remote sensing. Landsc. Urban Plan. 2006, 75, 69-80. [CrossRef]

56. Fung-Loy, K.; Van Rompaey, A.; Hemerijckx, L.M. Detection and Simulation of Urban Expansion and Socioeconomic Segregation in the Greater Paramaribo Region, Suriname. Tijdschr. Voor Econ. En Soc. Geogr. 2019, 110, 339-358. [CrossRef]

57. El Garouani, A.; Mulla, D.J.; El Garouani, S.; Knight, J. Analysis of urban growth and sprawl from remote sensing data: Case of Fez, Morocco. Int. J. Sustain. Built Environ. 2017, 6, 160-169. [CrossRef]

58. Höpfner, C.; Scherer, D. Analysis of vegetation and land cover dynamics in north-western Morocco during the last decade using MODIS NDVI time series data. Biogeosciences 2011, 8, 3359-3373. [CrossRef] 